\title{
Quality Development of Media Online Learning in Pandemic Era
}

\author{
Annisaa Soeyono ${ }^{1, \text { a) }}$ and Asty Khairi IS, ${ }^{2, \text { b) }}$ \\ 1, a Agribusiness Management Study Program, Vocational Study, IPB University, Kampus Cilibende, Jalan Kumbang No \\ 14, Bogor 16151 \\ 1, bAccounting Study Program, Vocational Study, IPB University, Kampus Cilibende, Jalan Kumbang No 14, Bogor 16151 \\ a)annisa.soe@apps.ipb.ac.id \\ ${ }^{b)}$ astykh@apps.ipb.ac.id
}

\begin{abstract}
The first quarter of 2020 is a hard time for the global community. The Coronavirus (COVID-19) pandemics swept through the world affected many aspects of human endeavour, such as the decline in industrial production to the re-adjustments in the academic calendar of all educational institutions globally. The purpose of this article is to examine online learning at the macro and micro level in terms of impact on college student. In this paper we discuss findings from evaluations we conducted and share experience we learned as developers of online education in several months. The authors collected fifteen lecturer of responden to investigate several online learning in Indonesian education as well as related research to level of satisfaction of college student and to speculate where it is going. The findings from the study revealed that students have adequate knowledge of the COVID-19 pandemic. Another finding that came up during the research is the high cost of participating in online learning. However, our results discovery that internet connectivity was very slow for students leaving within the dormitories of various universities. The findings from this study will be of much benefit to university administrators and management in taking future emergency decisions concerning the implementation of online learning programs for student's different backgrounds.
\end{abstract}

Keywords: college student, COVID-19 pandemic, higher educational institutions, lecturer, online learning.

\section{INTRODUCTION}

The first quarter of 2020 was a hard time for the global community. The Coronavirus (COVID-19) pandemics swept through the world affected many aspects, such as the economic recession, decline in industrial production to the re-adjustments in the academic calendar of all educational institutions globally. Based on data in BPS (2020): ONLY about 27,29\% from 100 educational services have been operate as usual (see figure attached). Distance education (English: distance education) is an institution-based formal education in which students and instructors are in separate locations so that it requires an interactive telecommunications system to connect the two and the various resources required in it. Electronic learning (e-learning) or online learning (online) is part of distance education that specifically combines electronic technology and internet-based technology. Distance education is not a new method in the education system. This learning method has been used in the United States since 1892 when the University of Chicago launched its first distance learning program for higher education. Distance learning methods continue to evolve using a variety of communication and information technologies including radio, television, satellite and the internet. One of the problems of distant learning is attendance. The 
presence of students during online learning is an absolute concern for lecturers, not only parents and the surrounding community. According to Abdul Rahim \& Chia [1], preventing student absenteeism is also a concern for all parties. Based on research by Zaliza, Mohd Safarin \& Ridzwan, students with attendance problems tend to have negative behavior. Vocational Education is education that is practice-oriented. Emphasis on what to do in the workplace to meet career requirements. Students must be able to take lessons and skills tests based on standards set by their field of work. The current generation of students has been exposed to internet technology and smart phones since early adolescence as stated by V. Gialamas. According to Sandars and Murray, students prefer to use technologies they are familiar with such as mobile networks, social media and blogs to obtain information. Valtonen and friends suggest that lecturers have their own way of negotiating student learning needs and how they should relate to students. Based on data in the last 5 (five) years, social media such as Facebook, Twitter, YouTube, Google+ and Wikipedia have dominated the way digital technology is now used around the world [2].

Vocational education in Indonesia prioritizes the mastery of skills and the closeness between the learning material taught and the knowledge needed in the world of work, which must be realized in the period of vocational education. The number of Vocational High Schools (SMK) in Indonesia reaches 1,1738 with details of 3,037 public and 8,701 private ones [3]. Based on data from DIKTI and Kemendikbud, the number of tertiary institutions in Indonesia is 4,273, while the number of high school and vocational high school graduates in 2014 is $2,804,664$. Higher education institutions in Indonesia have a limited capacity to absorb high school and vocational school graduates, which is only about 50 percent. The gross enrollment rate (GER) is the ratio of the number of students at a certain level to the number of people in the appropriate age group. The APK for higher education in Indonesia in 2014 only reached 30 percent. The GER of Indonesian tertiary institutions is expected to increase significantly to 60-70 percent in 2045. The condition of the number of SMK students increases by 200,000 each year and this time it is 4.3 million, while the target for 2019 is 5.5 million students [4]. Based on the results of preliminary observations on the use of the internet for learning in several vocational schools, the general condition of the internet network for learning is still lacking, especially in the use of e-learning. Almost all e-learning users in Vocational Education are not equipped with instructional designs. E-learning learning designs that are in accordance with vocational teaching materials will facilitate the management of e-learning itself so that the role of the teacher as a facilitator can be more focused on developing innovative learning in accordance with the learning objectives. Other problems related to the use of e-learning are web ownership, web updates, the amount of bandwidth, and students' interest in using computers for learning is still not being considered. Even though this condition is an important thing that must be optimized both in terms of performance and existence so that e-learning can take place properly and easily. To improve and facilitate the use of the internet for learning, an e-learning learning model is needed that can be used for various subjects in vocational subjects. Through research on the learning design model of e-learning vocational, guidelines will be generated on how to plan learning using e-learning. Making regulatory guidelines that make it easier for teachers to compile elearning learning designs requires determining criteria and indicators. These criteria and indicators will be used as guidelines in the implementation of e learning in SMK.

\section{LITERATURE REVIEW}

Distance learning (PJJ) is part of distance education which has been regulated in the Law of the Republic of Indonesia number 20 of 2003 regarding the national education system. Distance learning (PJJ) was initially limited to the Open University (UT), as the times other universities began to develop distance learning systems with the criteria stipulated in the Regulation of the Minister of Education and Culture No. 24 of 2012 concerning the implementation of distance education in universities. high. The distance learning law includes Law (UU) number 12 of 2012 concerning higher education Regulation of the minister of education and culture (Permendikbud) number 109 of 2013 concerning the implementation of distance education in higher education. E-learning which stands for Electronic Learning is a new way of teaching and learning that uses electronic media, especially the internet as a learning system. E-learning is the basis and logical consequence of the development of information and communication technology. Several experts have tried to describe the meaning of e-learning according to their respective versions, including: Rosenberg, emphasizing that elearning. PJJ can be done both Synchronously and ASynchronously. Allen and Seaman divided all courses into four groups: Traditional courses that do not use online technology. All material is given orally or in pen $\mathrm{x}$ The course is web facilitated using web-based technology. For example, a web page is used to provide syllabus and assignments (1-29\% of material is provided online) $x$ Mixed (hybrid) courses combine online learning and face-to-face classes (30-79\% are delivered online) $\mathrm{x}$ Online courses imply that a large proportion of all content (more than $80 \%$ ) is posted online [4].

The definition of E-Learning has many understandings, such as pure web-facilitated learning or 
mixed learning (either by using media or face-to-face. Elearning has actually been popularized since 1960, when the first Computer Based Training program (CBT program) was discovered. This program is also known as PLATO (Programmed Logic for Automated Teaching Operations). The program was created for students studying at the University of Illinois, but eventually the program was used in schools in almost all areas there. -It really only serves to convey information to students (trainees). But when entering the 70s, e-learning began to become more interactive. UK universities are eager to use e-learning. Their education system has focused on distance learning. At that time, the course material was delivered by post and communication with the teacher (trainer) is still by mail. Meanwhile, with the internet, Open Universities are starting to offer a wider range of interactive learning experiences as well as faster communication with students via e-mail. Then in 1990, when CBT was still popularly used, e-learning applications began to appear that ran on stand-alone PCs or in the form of CD-ROM packages. It contains written and multimedia material (video and audio) in mov, mpeg1 , or avi format. In 1994, these learning materials appeared in more attractive packages and were then mass produced.

The production of learning materials continued until the development of computers and the internet at the end of the 20th century and e-learning designs were also growing. The invention of the Mac in the 80 s allowed people to have a computer at home and made learning easier. Then in the following decades, virtual learning environments began to really develop, so that people could access information online. In 1997, the need for quickly obtainable information began to be perceived as an absolute necessity and distance and place were no longer obstacles. This is where the Learning Management System emerged. The rapid development of the Learning Management System (LMS) has made new ideas to solve the standard interoperability problem between one LMS and another. Forms of standards that have emerged include standards issued by the AICC (Airline Industry CBT Committee), IMS, SCORM, IEEE LOM, ARIADNE, and so on. Then around 2000, the development of LMS began to lead to web-based elearning applications. The web-based LMS application has grown in total, both for trainees, trainers and administrators. LMS began to be merged with information websites, magazines and newspapers. Its contents are also getting richer with a combination of multimedia, video streaming, and interactive displays in a wide selection of data formats

Many researchers define mixed learning as "a training method that combines the benefits of classroom learning and e-learning" [5][6]. The term "mixed learning" combines elements of face-to-face teaching, including personalized learning, social interaction and direct language contact, allowing for greater variety and flexibility than traditional learning. Implementing mixed learning in language class implies not only online learning, but also integrating content into lessons. We must distinguish between mixed learning and distance learning to prevent misunderstandings. Mixed learning aims to complement face-to-face sessions, while distance learning exists by itself. Mixed learning implies that receptive, writing and grammar skills must be performed individually and the teacher should concentrate on speaking and explaining the most difficult material, holding face-to-face classes. Understanding the main concepts of blended learning will help select suitable material for classroom discussions and individual student work. Only well-prepared and professional teachers can create mixed English courses that focus on listening, reading, writing, vocabulary, language exercises and pronunciation. Mixed learning has a number of advantages over traditional learning courses. The different in offline class and online class is Presentation, Quiz, Case study, Demonstration (Role Play), Textbook, Online Resource, Soft Skill (Interpersonal skill), Cognitive (ability to understand topic), Affection (pay attention to student condition), Psychomotor (abiity to demonstrate topic). In online class: Presentation, Quiz, Case study, Demonstration (Role Play), Textbook, Online Resource, Computer/Laptop, Network connection, Cognitive

Benefit of online learning system are can be done in eveywhere, time flexible, can be attended by a lot people and no need room meeting. Lack of online learning system are difficult to study, internet quota, lessconcentrate, infrastructure, network problem and lack of online study facility. Online media are curently used for example Google Form, Learning Management System (LMS), WebEx Cisco, Zoom, G-Meet, Skype, Ms team, WhatsApp Group, Youtube.

What online learning media are currently used: Google Form, Learning Management System (LMS), WebExc Cisco, Zoom Meeting, Google Meeting, Skype, Ms Team, WhatsApp Group, Youtube. Teaching and Learning Strategies The lecturer must be developed the kind of tools lecturing, make teaching learning strategies include case study, presentation and discussion. Get the main point and deep understanding by : Presentation (1 file per topic), Guideline by using Learning Outcomes, Textbook, Modul, Analytical thinking by making a real case, Grouph Discussion (WA), Personal and grouph assignment (real case), Get an issues for making discussion, Sharing knowledge, Guest Lecturer. 


\subsection{Structure the Lecturing}

Preparation: Lecturer's Material Presentation (Online Resource, Course outline, Textbook); Knowing your students (Program Study, Semester, GPA), Media Teaching (Audio, Visual); Scheduling \& Mode of Teaching

Introduction: Interest, Needs, Purpose, Topic, Outcomes, Assesment

Introduction, Body/Content: Body/Content, Lecturing with the practice, Give a time for making attention, Use online source (link, media), Lecturing by audio-visual

Closing: Ask the feedback, Discuss for the conclusion, Review the topic, Gain the thinking for future learning: Lecturing, Discussion (Forum Chat): Brainstorming, Case study, Role play, Sharing in pair; Question and Answer, Conclusion

\subsection{Source}

1. External: not all regions have good internet coverage, needs to be costly to go online (Internet Quota, pulsa), need a media device (laptop, handphone).

2. Internal:

a. Lecturer ability to make interesting presentation, ability to using multiple media learning.

b. Student: desire to learn (such as preparing before schedule), ability to understand quickly, lazy to attend the lecturing

\section{METHOD}

This study aimed to determine media online learning in lecturer and college student, that has been implemented during the pandemic COVID-19. The method we used is Descriptive Analysis with Purposive sampling. The Population of Respondents are Lecturer from various college, around Indonesia (from Medan to Papua). This paper discusses the findings from sharing experiences with several lecturers in implementing online learning in the last few months. The author used lecturer as research objects to collect data in investigating several online learning in Indonesian education. The survey was conducted by distributing questionnaires to all tertiary institutions in Indonesia. The data collected covers the main causes of online learning, what media are often used and what obstacles are often encountered.

\section{RESULT}

Based on the data I have obtained, there are 5 large groups of respondents. The groups are divided based on the domicile where they work, namely Papua (JayaPura), Sumatra (Medan), Kalimantan (Pontianak), Java (Semarang, Bandung, Madiun). The data that I take includes courses that have and are still using online learning media, commonly used media and teaching methods. I take Papua as an example, if it is taken an average of about $55.5 \%$ has applied online learning. Although not all. Because I only take samples randomly. For Kalimantan and Sumatra, the majority have also used online learning. For example, in Medan, it turns out that they have also implemented online learning before the pandemic occurred. This is indicated by a higher questionnaire result than in Kalimantan. I took data from 15 respondents spread across the region. For Java itself, it has a higher yield. This is because there have been many Open Universities, where the lecture system is conducted online.

Higher education institutions have their respective policies regarding the online lecture mechanism, one of which is the Vocational School (SV). SV is a practicebased university that is integrated with the industrial world. Currently, SV already has its own Learning Management System (LMS) to facilitate students and lecturers. The current condition can be said to be very favorable, because all are required to be able to conduct lectures online. Based on data obtained randomly, almost all universities have conducted online lectures. This is evidenced by the results obtained, which are presented in Figure 1 


\section{Online Learning Method}

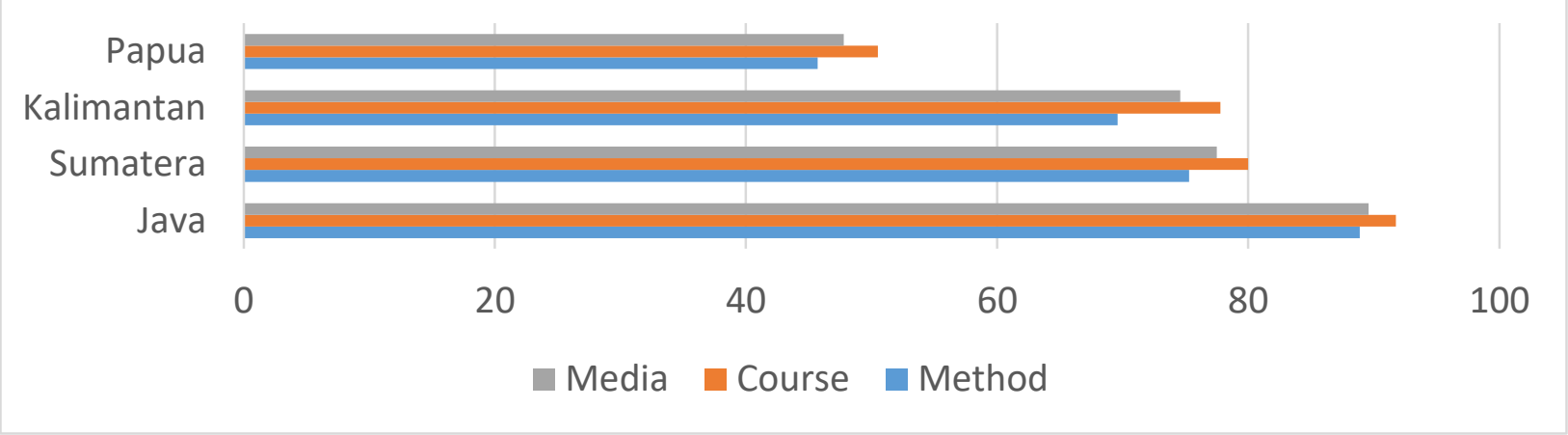

FIGURE 1. Online Learning Method from various university (Sumber: Private Document)

Here I also learned that there are 3 main factors that cause it: lecturer, student or technical. Based on the results, it turned out that there were more causes in MHWW. The reasons are various, such as feeling lazy to learn, difficulty in capturing material quickly, an unsupportive environment. It could be the economic condition of the parents or the circumstances when lecturing activities take place. If from the lecturers themselves, it is relatively low when compared with technical reasons. Because generally lecturers are able to quickly adapt to current conditions. Even though there are indeed several lecturers who complain of difficulties. Generally occurs in lecturers who are elderly. However, it doesn't really matter much. Because it can be helped by fellow lecturers to back up. From the technicality itself, in general it is more on the difficulty of network coverage, the absence of devices that can be used, and the selection of the most suitable media (Figure 2)

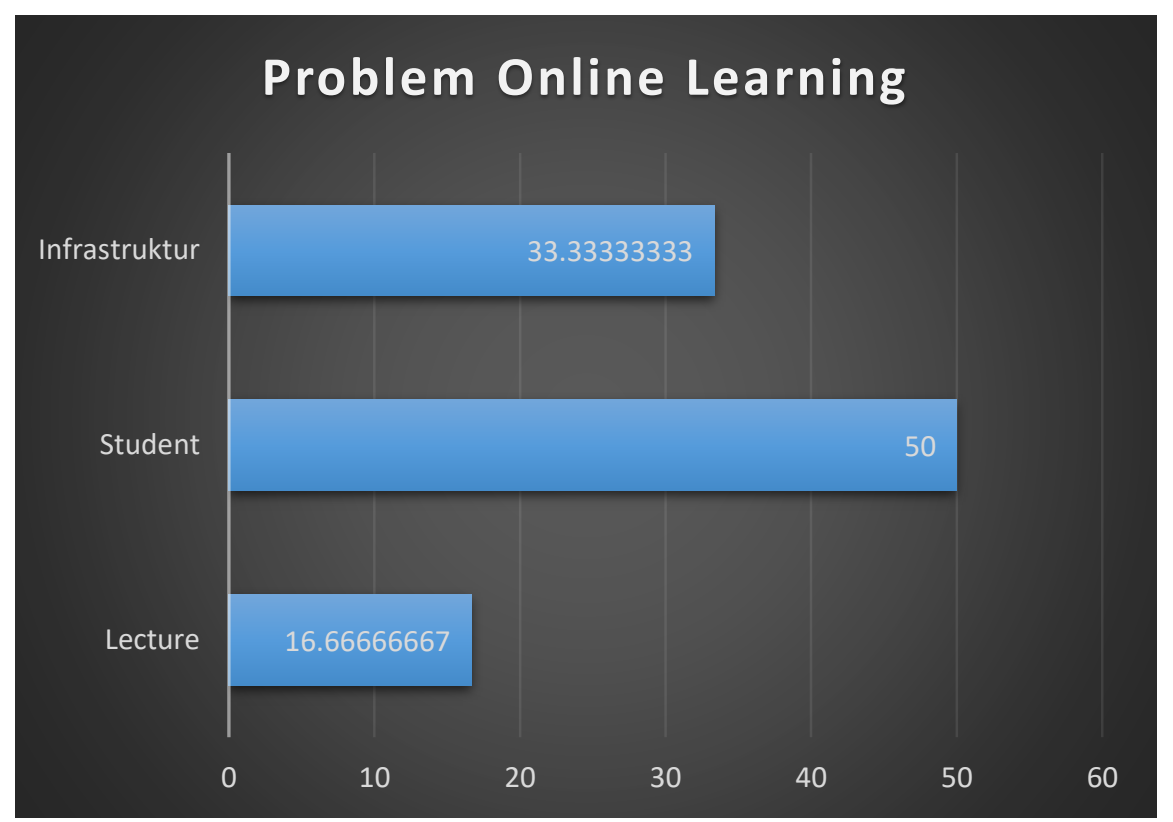

FIGURE 2. Problem Online Learning from various university (Source: Private Document)

These are some of the obstacles that are often encountered not only among students, but also by lecturers as course providers. In general, the media used by lecturers includes a combination of various types of media. Because it adapts to the needs of courses and students. If for lectures, the series uses zoom. Because it feels easier in terms of usage and quotas. However, there are also those who use g meet more for safety reasons. If it is for material that requires explanation of calculations, then it is added by using the white board application. Even though this is only a handful of people who know and do need more sophisticated devices. If it is for assignment submissions, it is preferable to use the g- 
classroom application because it can be set up as needed.

For communication, use WA.

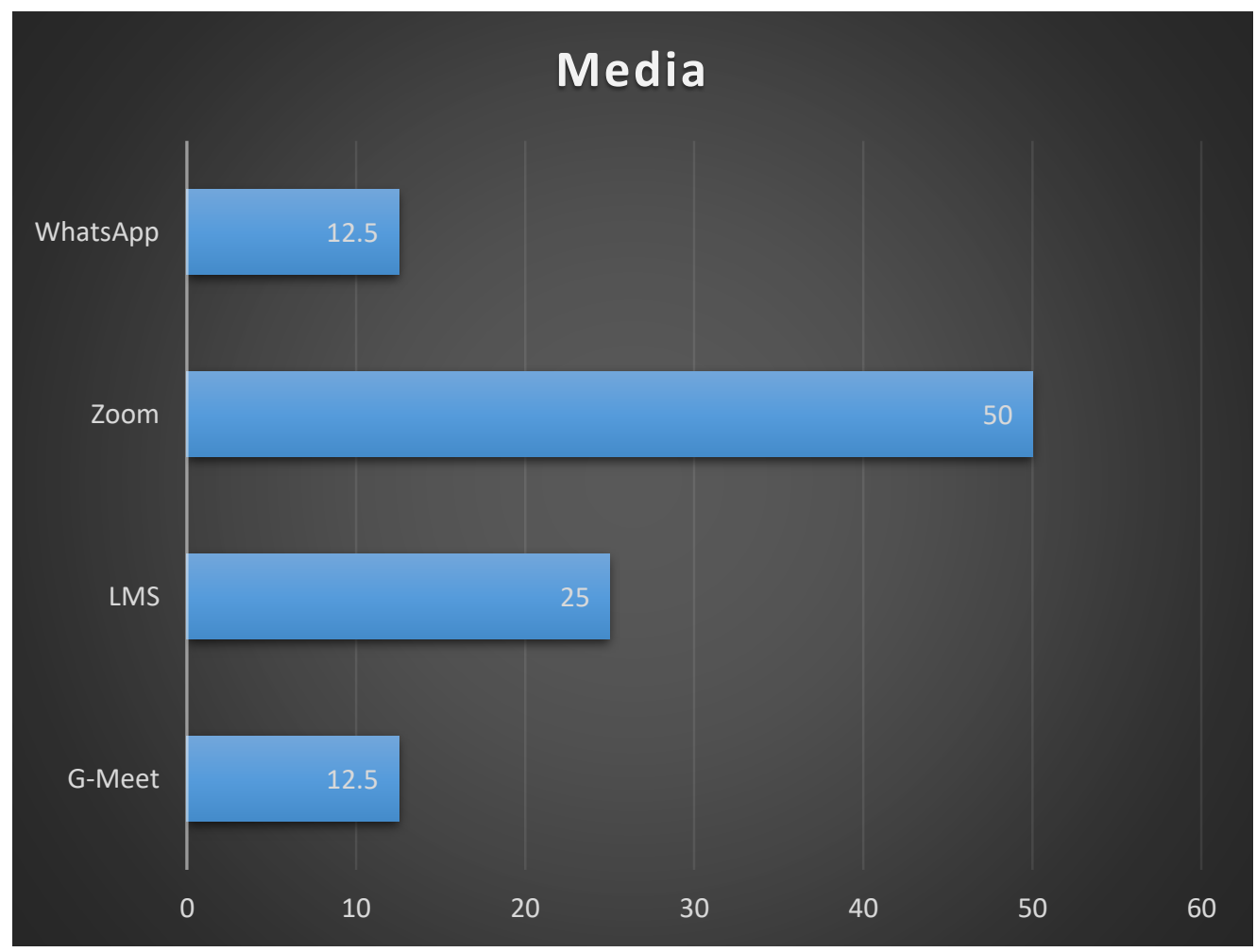

FIGURE 3. Media Online Learning. Souce: Privat Document

Currently, there are many other applications that can be used, such as LMS, Moodle. However, it takes more time to master. Even though activities must continue. So that for now, the use of these applications is only used part of the lecture class. The method used is still the same as during off-client cultivation, it's just that it focuses more on discussion. To avoid mshsw saturation and also use too much quota. In addition to stimulating students to be active and think critically. Sometimes we insert case studies and ask for instructional videos. Apart from the things mentioned earlier, there are still some obstacles that can be found such as:: Teaching materials that are more interesting and in accordance with online learning, there some of topic not suitable for online learning. multiply discussion and debate, share lecture materials. On time, the material is shared. Providing teaching materials, assignment modules and book resources students prefer face-to-face lectures

\section{CONCLUSION}

Currently, the infrastructure is still lacking, there are still many who are not ready, especially in the eastern region, so they still need improvement, actually they don't have to create new applications lecturers can be creative by using existing applications. There are 2 group as Synchronous and A-Synchronous. Synchronous used Online Meeting Plattform such as Zoom, G-Meet, Webex, and JoinWeBinar. In.A-Synchronoues, also used Online Moodle Plattform example G-Classroom, WAG, Moodle.inc, etc.

\section{REFERENCES}

[1] Abdul Rahim, H., \& Chia, L. La. (2014). Adakah Prestasi Sekolah Menjadi Penyumbang Utama Pengajaran Efektif? Sains Humanika, 2(1), 3540.

[2] Anonim. eBizMBA, 2014

[3] Anonim. 2019. http://datapokok.ditpsmk.net/

[4] Allen, I. E., \& Seaman, J. (2013). Changing Course: Ten Years of Tracking Online Education in the United States. Oakland: Babson Survey Research Group and Quahog Research Group, LLC 
[3] Anonim. 2019. http://datapokok.ditpsmk.net/

[4] Anonim. 2014.(http:

// acdpindonesia.wordpress.com/2014/08/25/1 Gradsmk-ready -bersaing /).

[5] Matukhin, D., et al., (2014). Methodological Basics of Blended Learning in Teaching English for Academic Purposes to Engineering Students. Asian SocialScience, 10(20), 97-102.

[6] Obskov A. V., et al. (2015). Educational Aspects of Interactive Foreign Language Learning in High Schools. Mediterranean Journal of Social Sciences MCSER Publishing, 6(4), S.4, 178-182. doi:10.5901/mjss.2015.v6n4s3p319. 